\title{
Forage mass and stocking rate of elephant grass pastures managed under agroecological and conventional systems
}

\section{Clair Jorge Olivo', Carlos Alberto Agnolin², Priscila Flôres Aguirre², Cláudia Marques de Bem², Tiago Luís da Ros de Araújo', Michelle Schalemberg Diehl², Gilmar Roberto Meinerz ${ }^{2}$}

\author{
${ }^{1}$ Departamento de Zootecnia, Universidade Federal de Santa Maria - Santa Maria, RS, Brasil. \\ 2 Programa de Pós-Graduação em Zootecnia, Universidade Federal de Santa Maria - Santa Maria, RS, Brasil.
}

\begin{abstract}
The objective was to evaluate elephant grass (Pennisetum purpureum Schum.) pastures, under the agroecological and conventional systems, as forage mass and stocking rate. In the agroecological system, the elephant grass was established in rows spaced by $3.0 \mathrm{~m}$ from each other. During the cool season ryegrass (Lolium multiflorum Lam.) was established between these rows, which allowed the development of spontaneous growth species during the warm season. In the conventional system the elephant grass was established singularly in rows spaced $1.4 \mathrm{~m}$ from each other. Organic and chemical fertilizers were applied at $150 \mathrm{~kg}$ of N/ha/year with in the pastures under agroecological and conventional systems, respectively. Lactating Holstein cows which received $5.0 \mathrm{~kg}$ /day supplementary concentrate feed were used for evaluation. The experimental design was completely randomized, with two treatments (agroecological and conventional systems) two replications (paddocks) and independent evaluations (grazing cycles). The pastures were used during the whole year for the agroecological system and for 195 days in the conventional year. The average values of forage mass were 3.5 and $4.2 \mathrm{t} / \mathrm{ha}$ and the stocking rates were 2.08 and $3.23 \mathrm{AU} /$ ha for the respective systems. The results suggest that the use of the elephant grass under the agroecological system allows for best distribution of forage and stocking rate to be more uniform throughout the year than the use of elephant grass in conventional system.
\end{abstract}

Key Words: lactating cows, Lolium multiflorum, Pennisetum purpureum, production systems, rotational stocking

\section{Introduction}

Elephant grass has been used in different Brazilian regions, mainly because of its high potential for forage production. Its use in pasture conditions has increased due to the improvement in the quality of forage offered and reduction in the involved manpower compared with its use as cutting forage.

Elephant grass is usually established alone in conventional agricultural farms. The farms that use elephant grass adopt the conventional production strategy based on productivity, which is established singularly. Soil nutrients are replenished mainly with chemical fertilizers. In dairy small farms it is notable that elephant grass has been found as an alternative in animal nutrition. In different Brazilian regions high stocking rate was achieved, from 4 to 8 cows/ha (Deresz et al., 2001). Despite the high performance, research has many times revealed problems such as increase in production costs, mainly for nitrogen fertilizers and rangeland

Received September 10, 2012 and accepted February 18, 2014

Corresponding author: clairo@smail.ufsm.br

http://dx.doi.org/10.1590/S1516-35982014000600002

Copyright $(\subset 2014$ Sociedade Brasileira de Zootecnia. This is an Open Access article distributed under the terms of the Creative Commons Attribution Non-Commercial License, which permits unrestricted non-commercial use, distribution, and reproduction in any medium, provided the original work is properly cited. degradation (Dall'agnol et al., 2004; Deresz et al., 2006). It is worth noting that in this system the use is concentrated in the warm season in the south region, with a great variability in forage production between the grazing cycles.

The management forms, inputs and technologies used in the agroecological strategy based on optimization of production are usually more appropriate to preserve the natural resource base, providing higher stability for the productive system. This type of agriculture involves perennial grasses, mixture of species, organic fertilization, and no use of pesticides. Thus, the objective of this experiment was to evaluate the forage mass and the stocking rate of elephant grass pastures managed under agroecological and conventional systems throughout four years.

\section{Material and Methods}

The study was conducted according to ethical standards and approved by the Ethics and Biosafety Committee by Protocol 23081016073/2011-27, in number 113/2011.

The experiment was conducted in the Dairy Cattle Laboratory of the Department of Animal Science in Universidade Federal de Santa Maria (UFSM), located in the physiographic region called Central Depression of Rio Grande do Sul (Brazil), at the altitude of $95 \mathrm{~m}$, South 
latitude $29^{\circ} 43^{\prime}$ and West longitude $53^{\circ} 42^{\prime}$. The soil of the experimental area is classified as red eutrophic argisol, belonging to the Sao Pedro mapping unit (Streck et al., 2002). The climate of the region is Cfa (humid subtropical), according to the Köppen classification (Moreno, 1961). The average temperature and monthly precipitation in the region are $18.5^{\circ} \mathrm{C}$ and $142 \mathrm{~mm}$, respectively.

The research was conducted from May 2006 to April 2010. The average temperature, monthly precipitation and the number of frosts were $19.1{ }^{\circ} \mathrm{C} ; 141 \mathrm{~mm}$ and 20, respectively (Figure 1). From April to November the average temperature, monthly precipitation and number of frosts were $15.9^{\circ} \mathrm{C}, 107 \mathrm{~mm}$ and 11 in $2006 ; 16.7^{\circ} \mathrm{C}, 120 \mathrm{~mm}$ and 22 in $2007 ; 15.7^{\circ} \mathrm{C}, 140 \mathrm{~mm}$ and 11 in 2008 ; and $15.5^{\circ} \mathrm{C}$, $174 \mathrm{~mm}$ and 22 in 2009. The data was collected at the UFSM Meteorological Experiment Station, located about $500 \mathrm{~m}$ away from the experimental site.

For the experiment, four paddocks of 0.12 ha each were managed separately during four years, each one in its production system (agroecological and conventional), stated in the treatment of the present study.

In the agroecological system managed according to principles contained in Instruction 46 of the Ministry of Agriculture Livestock and Food Supply (Brasil, 2011), the elephant grass (Pennisetum purpureum Schum.), cultivar Merckeron Pinda, was established for twelve years in rows spaced by $3.0 \mathrm{~m}$ from each other. In May of each year ryegrass common cultivar (Lolium multiflorum Lam.) was sown between the rows of elephant grass, at a rate of $30 \mathrm{~kg} / \mathrm{ha}$, by scarifying the soil. In the warm season, the development of spontaneous growth species was allowed.

Soil analysis presented the following mean values at the beginning of the experimental period: SMP Index 6.4; $\mathrm{P}, 8.4 \mathrm{mg} \mathrm{dm}{ }^{-3} ; \mathrm{K}, 48 \mathrm{mg} / \mathrm{dm}^{3} ; \mathrm{Al}^{3+}, 0.0 \mathrm{cmol}_{\mathrm{c}} \mathrm{dm}^{-3} ; \mathrm{Ca}^{2+}$, $6.6 \mathrm{cmol}_{\mathrm{c}} \mathrm{dm}^{-3} ; \mathrm{Mg}^{2+}, 3.6 \mathrm{cmol}_{\mathrm{c}} \mathrm{dm}^{-3}$; OM, 2.3\%; base

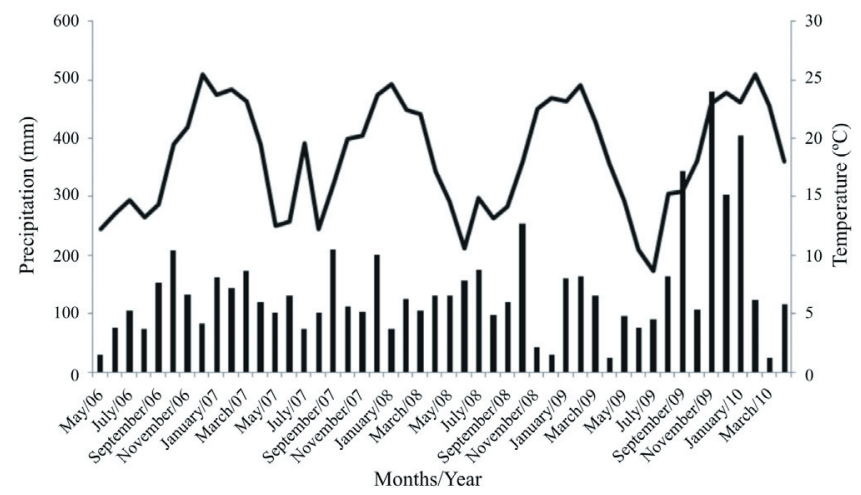

Figure 1 - Monthly precipitation $(\mathrm{mm})$ and average temperature $\left({ }^{\circ} \mathrm{C}\right)$ from May 2006 to May 2010. saturation, $78.3 \%$ and aluminum saturation, $0.0 \%$. The fertilizer used had a N-P $\mathrm{O}_{5}-\mathrm{K}_{2} \mathrm{O}$ rate of $150-80-70 \mathrm{~kg} / \mathrm{ha} /$ year, consisting of cattle manure, collected from the standby hose, with $35 \%$ of dry matter (DM), and of pig slurry with $5 \%$ of DM. The chemical composition of cattle manure, on a DM basis, was $1.20,0.45$ and $0.62 \%$ of $\mathrm{N}, \mathrm{P}_{2} \mathrm{O}_{5}$ and $\mathrm{K}_{2} \mathrm{O}$, respectively. The chemical composition of pig slurry, on a DM basis, was $2.80,1.90$ and $0.90 \%$ of $\mathrm{N}, \mathrm{P}_{2} \mathrm{O}_{5}$ and $\mathrm{K}_{2} \mathrm{O}$, respectively. Fertilization was performed twice a year: in the cool season (30\%) and in the warm season $(70 \%$ of the volume).

In the conventional system the elephant grass was established singularly in rows spaced by $1.4 \mathrm{~m}$ from each other. Fertilization was performed in September of each year, based on the soil analysis, in which on average $40-80-70 \mathrm{~kg} / \mathrm{ha}$ of $\mathrm{N}-\mathrm{P}_{2} \mathrm{O}_{5}-\mathrm{K}_{2} \mathrm{O}$ were used; the urea-based nitrogen fertilization was $110 \mathrm{~kg} / \mathrm{ha}$ fractionated into four applications.

The rotational grazing method was adopted, with occupation time of one to two days. The criteria for the grazing onset in the warm season (in both pastures) was the sward height of elephant grass, when it was around $1.2 \mathrm{~m}$; in the cool season (in the agroecological system), the criteria was the height of ryegrass (about $20 \mathrm{~cm}$ ). Before the beginning of grazing, samples were collected to estimate forage mass using the double sampling technique with 5 cuts and 20 visual estimates (Mannetje et al., 1978). The elephant grass was cut at $50 \mathrm{~cm}$ from the soil. In the agroecological system the forage between the elephant grass rows were sampled at the ground level. The samples were weighed and homogenized, collecting a sub sample to determine the botanical composition of the pastures and of the structural components of the elephant grass. The levels of dry matter were determined for all samples, by oven drying at $105^{\circ} \mathrm{C}$ for 8 hours.

The stocking rate in the conventional pasture was calculated based on leaf blade allowance of elephant grass at $4 \mathrm{~kg}$ of dry matter per $100 \mathrm{~kg}$ body weight; in the agroecological system the same forage allowance was used considering one-third of the area occupied by the elephant grass; for the remaining two-thirds the proportional stocking rate was calculated aiming to maintain the forage allowance between 8 and $10 \mathrm{~kg}$ of dry forage mass per $100 \mathrm{~kg}$ of body weight. Lactating Holstein cows with $543 \mathrm{~kg}$ average body weight and $20.4 \mathrm{~kg}$ /day milk production which received $5.0 \mathrm{~kg}$ /day supplementary concentrate feed were used for the evaluation.

The experimental design was completely randomized with two treatments (forage systems), two replicated areas (paddocks) and independent evaluations (grazing cycles). 
The production systems were analyzed in each year. All data were subjected to analysis of variance and the means were compared by the $\mathrm{F}$ test at $5 \%$ probability. The analyses were made with the SAS (Statistical Analysis System, version 9.2) statistical package (2001). The statistical model referring to the analyzed variables was represented as:

$$
\mathrm{Y}_{\mathrm{ijkl}}=\mathrm{m}+\mathrm{T}_{\mathrm{i}}+\mathrm{R}_{\mathrm{j}}\left(\mathrm{T}_{\mathrm{i}}\right)+\mathrm{G}_{\mathrm{k}}+(\mathrm{TG})_{\mathrm{ik}}+\mathrm{C}_{1}+(\mathrm{GC})_{\mathrm{kl}}+\varepsilon_{\mathrm{ijk} l} \text {, }
$$

in which: $\mathrm{Y}_{\mathrm{ijkl}}=$ dependent variables; $\mathrm{i}=$ treatment indexes (forage systems); $\mathrm{j}=$ repetition indexes (paddocks); $\mathrm{k}=$ grazing cycle indexes; $1=$ crop year; $\mathrm{m}=$ average for all reports; $T_{i}=$ effect caused by the treatments; $R_{j}\left(T_{i}\right)=$ effect of repetition in treatments (error $a$ ); $G_{k}=$ effect of grazing cycles; $(\mathrm{TG})_{\mathrm{ik}}=$ interaction between treatments and the grazing cycles; $\mathrm{C}_{1}=$ effect of crop year; $(\mathrm{GC})_{\mathrm{kl}}=$ interaction between treatments and the crop year; and $\varepsilon_{\mathrm{ijkl}}=$ residual experimental error (error b).

\section{Results and Discussion}

During the experimental period in the agroecological system, seven, six, eight and seven grazing cycles occurred in the respective crop years between May 2006 and April 2010; in the cool season there were three, two, four and four grazing cycles, respectively (Table 1).

The forage mass over the four years evaluated was varied, proven by the year $\times$ grazing cycle interaction $(\mathrm{P}<0.05)$.

For the elephant grass managed under conventional system, there were four and seven grazing cycles in the crop years 2006-2008 and 2008-2010, respectively (Table 1). The lower number of grazing cycles in the cool season between 2006 and 2007 was due to low rainfall between February and May, an average of $56.5 \mathrm{~mm}, 42 \%$ lower than the normal values, and also due to the low temperatures and high number of frosts observed in this period. In the next year (2007-2008) the lower number of grazing cycles in the cool season was also due to the low temperatures. In the following two crop years there was a possibility of elephant grass use due to mild temperature conditions, where frosts occurred much later.

Evaluating the agroecological system in the cool season, the association between ryegrass and elephant grass is beneficial for the animals, since while the winter culture initially contains a highly value of protein and digestibility and lower fiber, the warm season shows an inverse trend for these variables (Olivo et al., 2007). This condition is appropriate for the animals that have better possibilities of balancing their diet. It is also observed that an occurrence of cumulative frosts, searing the elephant grass leaves and the top of the stems, contributes to the protection of clumps and perpetuation of culture, since the animals consume little elephant grass in these phenological conditions. In contrast, one of the ways to increase the number of grazing cycles in the cool season is introducing oats (Sobczack et al., 2005) due to their precocity in association with ryegrass, which is a later culture.

During the evaluation of the pastures in the warm season, the grazing cycles varied from 30 to 37 days, considered appropriate (Fonseca et al., 1998). Grazing cycles with an occupation period of two to three days for tropical species, associated with rest periods of 30 days, are related to the higher forage quality and to the better animal performance (Deresz et al., 2001; Soares et al., 2004).

For the forage mass in the agroecological system there was little variability between the evaluations and crop years, compared with the conventional system, where the average was $3.6 \mathrm{t} / \mathrm{ha}$ in the cool season and $3.8 \mathrm{t} / \mathrm{ha}$ in the warm season. It should be noted, however, that the elephant grass, occupying about one-third of the area during the cool season, showed $38.4 \%$ of leaf blades as the average of four years (Table 2). This proportion is important in this forage system, since, despite the low development rate in this period, it shows an increase in the nutritive value of green forage (Olivo et al., 2007). The high levels of straw observed in the dead material fraction may also constitute a major component for balancing the fibrous diet of cattle as well as protecting some stem parts from the frosts. Strategically, we emphasize the importance of elephant grass production in the fall, due to the low availability of forage that normally is verified in this period on dairy farms in the South of Brazil. In the warm season the values of forage mass were higher due to the contribution of elephant grass (Table 1).

For the forage between the rows (occupying two-thirds of the area) there is a uniformity of forage mass during the evaluations of each crop year. The participation was $36.7 \%$ in the cool season, consisting mainly of ryegrass; in the warm season it was $28.4 \%$ based on species of the genus Paspalum spp., along with others such as Urochloa plantaginea (Link) Hitche and Sida santaremnensis H. Monteiro.

In the conventional system the forage mass is concentrated in the period of higher development rates of the crop in summer, superior for the mean values $(\mathrm{P}<0.05)$ in relation to the agroecological system, due to this behavior and its higher production yield. Evaluating the forage mass during the crop years, we observed that the highest measures occurred between 2006 and 2007, partly due to the non-use of the pasture during the cool season (Table 1); between December and January, both in 2007-2008 and 2008-2009, there was lower availability of forage due to the attack by spittlebug (Deois flavopicta Stal, Homoptera: Cercopidae), which infested both pasture systems. Control 
was performed with a biological insecticide (METARRIL ${ }^{\circledR}$ ) that uses spores of Metarhizium anisopliae fungal as an active ingredient.

The average values obtained in both systems (Table 1) are similar to that found by Restle et al. (2002), in Rio Grande do Sul in a forage system with Taiwan A-146 cultivar elephant grass alone, evaluated between December and April but fertilized with $500 \mathrm{~kg} / \mathrm{ha}$ of nitrogen. A similar response was also observed by Lima et al. (2004), in Sao Paulo, who evaluated the Guaçu cultivar fertilized with $250 \mathrm{~kg} / \mathrm{ha}$ of nitrogen in the same period.

For the stocking rate (Table 1), the mean values were 2.1 and 3.3 AU/ha considering the crop year for the agroecological system and 198 days for the conventional system. Considering the average time on the agroecological system (365 days), the stocking rate for the conventional

Table 1 - Forage mass stocking rate and structural composition of elephant grass under agroecological (AGR) and conventional (CNV) systems in four years of evaluation (2006-2010)

\begin{tabular}{|c|c|c|c|c|c|c|c|c|c|c|c|}
\hline \multirow{3}{*}{ Parameter } & \multirow{3}{*}{ System } & \multicolumn{8}{|c|}{ Grazing cycles } & \multirow{3}{*}{ Average } & \multirow{3}{*}{$\mathrm{CV}(\%)$} \\
\hline & & \multicolumn{3}{|c|}{ Cool season } & \multicolumn{5}{|c|}{ Warm season } & & \\
\hline & & $\begin{array}{c}1 \mathrm{st} \\
\text { (Jul) }\end{array}$ & $\begin{array}{l}\text { 2nd } \\
\text { (Aug) }\end{array}$ & $\begin{array}{c}3 \mathrm{rd} \\
(\mathrm{Oct})\end{array}$ & $\begin{array}{c}1 \mathrm{st} \\
(\mathrm{Dec})\end{array}$ & $\begin{array}{l}2 \text { nd } \\
(\operatorname{Jan})\end{array}$ & $\begin{array}{c}3 \mathrm{rd} \\
(\mathrm{Feb})\end{array}$ & $\begin{array}{c}\text { 4th } \\
\text { (Mar) }\end{array}$ & $\begin{array}{c}5 \text { th } \\
\text { (Apr) }\end{array}$ & & \\
\hline \multicolumn{12}{|c|}{$2006-2007$} \\
\hline \multirow[t]{3}{*}{ Forage mass (kg DM/ha) } & AGR & $3284 \mathrm{C}$ & $4237 \mathrm{~B}$ & 4495B & $6479 \mathrm{~A}$ & $6361 \mathrm{~A}$ & $6306 \mathrm{~A}$ & $5559 \mathrm{~A}$ & - & $5246 b$ & 17.7 \\
\hline & $\mathrm{CNV}$ & - & - & - & $10945 \mathrm{C}$ & 14339B & $18785 \mathrm{~A}$ & $16768 \mathrm{~A}$ & - & $15209 a$ & 10.5 \\
\hline & $\mathrm{CV}(\%)$ & - & - & - & 7.6 & 6.4 & 5.3 & 5.9 & - & & \\
\hline \multirow[t]{3}{*}{ EGFM (kg DM/ha) } & AGR & $2601 \mathrm{C}$ & $2972 \mathrm{C}$ & $3224 \mathrm{C}$ & $5373 \mathrm{~A}$ & $5433 \mathrm{~A}$ & $5475 \mathrm{~A}$ & 4314B & - & $4199 b$ & 23.3 \\
\hline & $\mathrm{CNV}$ & - & - & - & $10945 \mathrm{C}$ & 14339B & $18785 \mathrm{~A}$ & $16768 \mathrm{~A}$ & - & $15209 a$ & 10.8 \\
\hline & $\mathrm{CV}(\%)$ & - & - & - & 8.4 & 6.9 & 5.6 & 6.5 & - & & \\
\hline FMBR (kg DM/ha) & AGR & $683 \mathrm{C}$ & $1265 \mathrm{~A}$ & $1271 \mathrm{~A}$ & 1106B & 929B & $830 \mathrm{~B}$ & $1245 \mathrm{~A}$ & - & 1047 & 23.5 \\
\hline \multirow[t]{3}{*}{ Stocking rate $(\mathrm{kg} \mathrm{BW} / \mathrm{ha})$} & AGR & $27387 \mathrm{E}$ & 39469D & $34526 \mathrm{D}$ & $49713 \mathrm{C}$ & $44867 \mathrm{C}$ & $65230 \mathrm{~A}$ & $55040 \mathrm{~B}$ & - & $45176 \mathrm{a}$ & 7.4 \\
\hline & $\mathrm{CNV}$ & - & - & - & $6073 \mathrm{C}$ & 7904B & $11820 \mathrm{~A}$ & $7702 \mathrm{~B}$ & - & $8375 b$ & 8.3 \\
\hline & $\mathrm{CV}(\%)$ & - & - & - & 4.7 & 5.0 & 3.4 & 4.2 & & & \\
\hline \multicolumn{12}{|c|}{ 2007-2008 } \\
\hline \multirow[t]{3}{*}{ Forage mass (kg DM/ha) } & AGR & - & $2737 \mathrm{C}$ & $6952 \mathrm{~A}$ & $3537 \mathrm{~B}$ & - & - & 1790D & 1879D & 3379 & 17.7 \\
\hline & CNV & - & - & - & $1871 \mathrm{C}$ & - & 2188B & 2491A & 2013B & 2141 & 10.5 \\
\hline & $\mathrm{CV}(\%)$ & - & - & - & 24.4 & - & - & 20.8 & 23.9 & & \\
\hline \multirow[t]{3}{*}{ EGFM (kg DM/ha) } & AGR & - & 1999D & $6952 \mathrm{~A}$ & 2110B & - & 2188B & $1790 \mathrm{C}$ & $1778 \mathrm{C}$ & 2803 & 23.3 \\
\hline & CNV & - & - & - & $1871 \mathrm{C}$ & - & - & 2491A & 2013B & 2125 & 10.8 \\
\hline & $\mathrm{CV}(\%)$ & - & - & - & 24.2 & - & - & 21.8 & 25.9 & & \\
\hline FMBR (kg DM/ha) & AGR & - & 739C & - & $1427 \mathrm{~A}$ & - & - & 1268B & 100D & 884 & 23.5 \\
\hline \multirow[t]{3}{*}{ Stocking rate (kg BW/ha) } & AGR & - & $25631 \mathrm{C}$ & 48326A & 36331B & - & - & $19662 \mathrm{D}$ & $12202 \mathrm{D}$ & $28430 a$ & 7.4 \\
\hline & CNV & - & - & - & 918B & - & $1053 \mathrm{~B}$ & 1191A & 914B & $962 b$ & 8.3 \\
\hline & $\mathrm{CV}(\%)$ & - & - & - & 7.1 & - & - & 12.6 & 20.1 & & \\
\hline \multicolumn{12}{|c|}{ 2008-2009 } \\
\hline \multirow[t]{3}{*}{ Forage mass (kg DM/ha) } & AGR & 2914B & $2486 \mathrm{C}$ & $3454 \mathrm{Ba}$ & $4119 \mathrm{Aa}$ & $2739 \mathrm{Ba}$ & 2993Bb & $3816 \mathrm{Ab}$ & $2863 \mathrm{~B}$ & 3173 & 17.7 \\
\hline & CNV & $4430 \mathrm{C}$ & - & $740 \mathrm{~Eb}$ & $2170 \mathrm{Db}$ & $535 \mathrm{~Eb}$ & 6192B & $6621 \mathrm{Aa}$ & $3051 \mathrm{D}$ & 3391 & 10.5 \\
\hline & CV $(\%)$ & 18.0 & - & 21.5 & 21.0 & 20.3 & 14.4 & 12.6 & 22.3 & & \\
\hline \multirow[t]{3}{*}{ EGFM (kg DM/ha) } & AGR & $2361 \mathrm{Ab}$ & $1442 \mathrm{C}$ & $2254 \mathrm{~A}$ & $2765 \mathrm{~A}$ & $2187 \mathrm{Aa}$ & $1948 \mathrm{Bb}$ & $2615 \mathrm{Ab}$ & $1509 \mathrm{C}$ & 2135 & 23.3 \\
\hline & $\mathrm{CNV}$ & $4430 \mathrm{Ca}$ & - & $740 \mathrm{~F}$ & $2170 \mathrm{E}$ & $535 \mathrm{Fb}$ & 6192Ba & $6621 \mathrm{Aa}$ & $3051 \mathrm{D}$ & 3391 & 10.8 \\
\hline & $\mathrm{CV}(\%)$ & 20.0 & - & 25.5 & 27.6 & 20.1 & 16.7 & 14.7 & 29.9 & & \\
\hline FMBR (kg DM/ha) & AGR & $553 \mathrm{~B}$ & $1045 \mathrm{~A}$ & $1200 \mathrm{~A}$ & $1353 \mathrm{~A}$ & $553 \mathrm{~B}$ & $1045 \mathrm{~A}$ & $1200 \mathrm{~A}$ & $1353 \mathrm{~A}$ & 1038 & 23.5 \\
\hline \multirow[t]{3}{*}{ Stocking rate $(\mathrm{kg} \mathrm{BW} / \mathrm{ha})$} & AGR & 2017Aa & $560 \mathrm{C}$ & $729 B$ & $1210 \mathrm{~A}$ & $458 \mathrm{C}$ & $1202 \mathrm{Ab}$ & $1203 \mathrm{~A}$ & $1061 \mathrm{Ab}$ & 1055 & 7.4 \\
\hline & CNV & $377 \mathrm{Db}$ & - & $738 \mathrm{C}$ & $862 \mathrm{C}$ & $629 \mathrm{C}$ & $3648 \mathrm{Aa}$ & 4196A & $1850 \mathrm{Ba}$ & 1757 & 8.3 \\
\hline & $\mathrm{CV}(\%)$ & 10.0 & - & 18.0 & 12.7 & 24.3 & 5.4 & 4.9 & 9.0 & & \\
\hline \multicolumn{12}{|c|}{$2009-2010$} \\
\hline Forage mass (kg DM/ha) & AGR & - & $3241 B$ & $2266 \mathrm{C}$ & $2837 \mathrm{C}$ & $2318 \mathrm{Cb}$ & $2582 \mathrm{C}$ & $5474 \mathrm{~A}$ & 3744B & 3209 & 17.7 \\
\hline & $\mathrm{CNV}$ & - & $5695 \mathrm{Ba}$ & $3055 \mathrm{D}$ & $4295 \mathrm{C}$ & 7809Aa & $2685 \mathrm{D}$ & $5368 \mathrm{~B}$ & $2330 \mathrm{E}$ & 4462 & 10.5 \\
\hline & $\mathrm{CV}(\%)$ & - & 14.8 & 24.8 & 18.5 & 13.0 & 25.0 & 12.2 & 21.7 & & \\
\hline EGFM (kg DM/ha) & AGR & - & $1930 \mathrm{Cb}$ & $1312 \mathrm{Cb}$ & $1406 \mathrm{Cb}$ & $1219 \mathrm{Cb}$ & $1551 \mathrm{C}$ & $3637 \mathrm{~A}$ & 2951B & 2001 & 23.3 \\
\hline & CNV & - & $5695 \mathrm{Ba}$ & 3054Da & $4295 \mathrm{Ca}$ & 7809Aa & $2685 \mathrm{D}$ & $5368 B$ & 2330D & 4462 & 10.8 \\
\hline & $\mathrm{CV}(\%)$ & - & 17.9 & 21.2 & 23.9 & 15.1 & 22.1 & 15.1 & 25.8 & & \\
\hline FMBR (kg DM/ha) & AGR & - & $1311 \mathrm{~A}$ & $954 \mathrm{~B}$ & $1432 \mathrm{~A}$ & 1099A & $1032 \mathrm{~A}$ & $1837 \mathrm{~A}$ & $793 B$ & 1208 & 23.5 \\
\hline Stocking rate (kg BW/ha) & AGR & - & $419 \mathrm{Cb}$ & $767 \mathrm{Bb}$ & $885 B$ & $1180 \mathrm{~A}$ & $1183 \mathrm{~A}$ & $1452 \mathrm{~A}$ & $464 \mathrm{C}$ & 907 & 7.4 \\
\hline & $\mathrm{CNV}$ & - & $800 \mathrm{Da}$ & $1202 \mathrm{Ca}$ & 1679B & $2265 \mathrm{~A}$ & $1025 \mathrm{C}$ & 1598B & $350 \mathrm{E}$ & 1274 & 8.3 \\
\hline & CV $(\%)$ & - & 21.6 & 13.4 & 10.3 & 7.7 & 11.9 & 8.6 & 22.4 & & \\
\hline
\end{tabular}

DM - dry matter; EGFM - elephant grass forage mass; FMBR - forage mass between the rows of elephant grass; BW - body weight; CV - coefficient variation. Means followed by the same lowercase letters (column) and uppercase letters (row) differ significantly at $5 \%$ probability. 
Table 2 - Structural composition of elephant grass under agroecological (AGR) and conventional (CNV) systems in four years of evaluation (2006-2010)

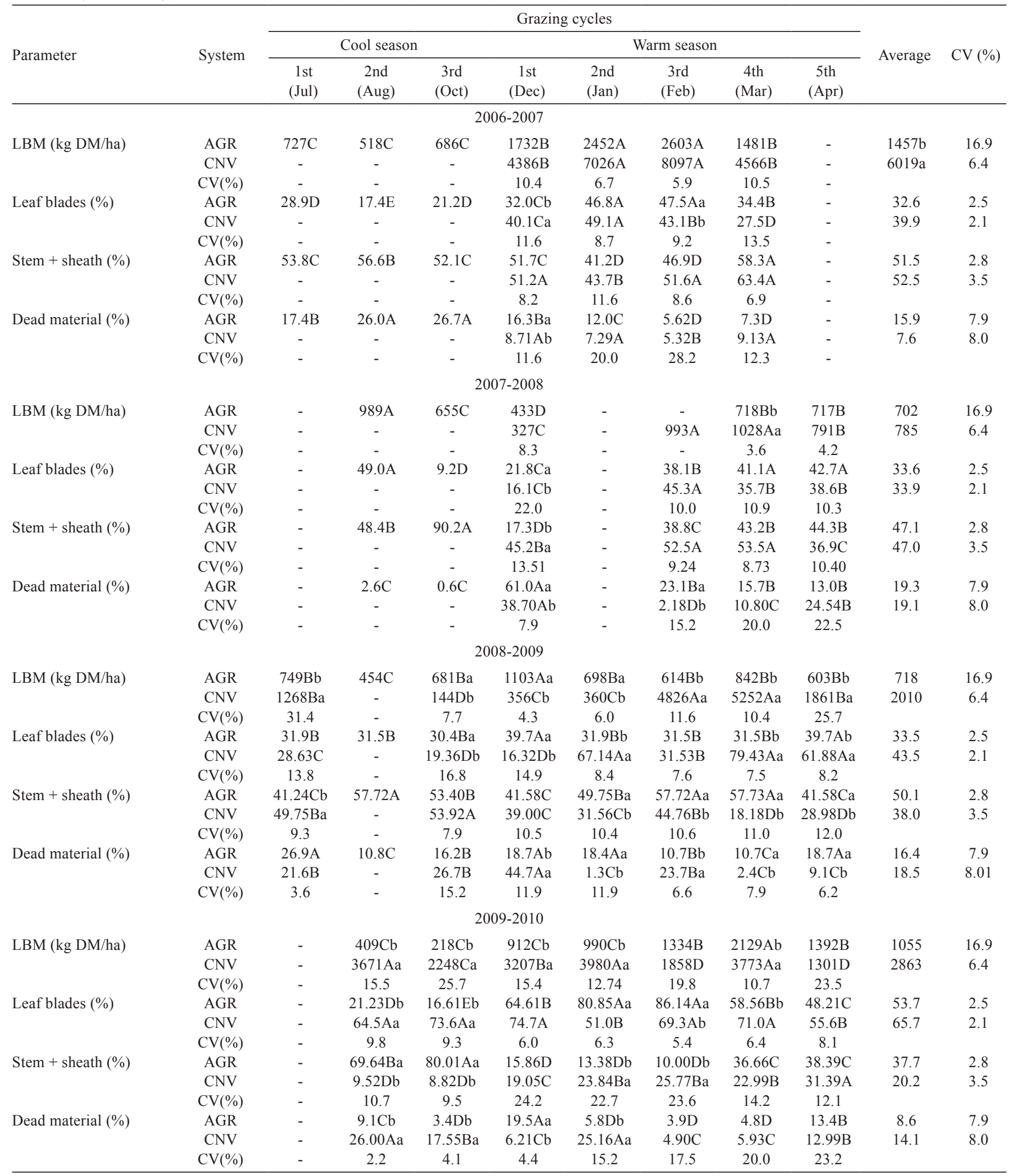

DM - dry matter; LBM - biomass of leaf blades of the elephant grass; CV - coefficient variation.

- : absence of the component.

Means followed by the same uppercase letters (column) and lowercase letters (row) differ significantly at $5 \%$ probability. 


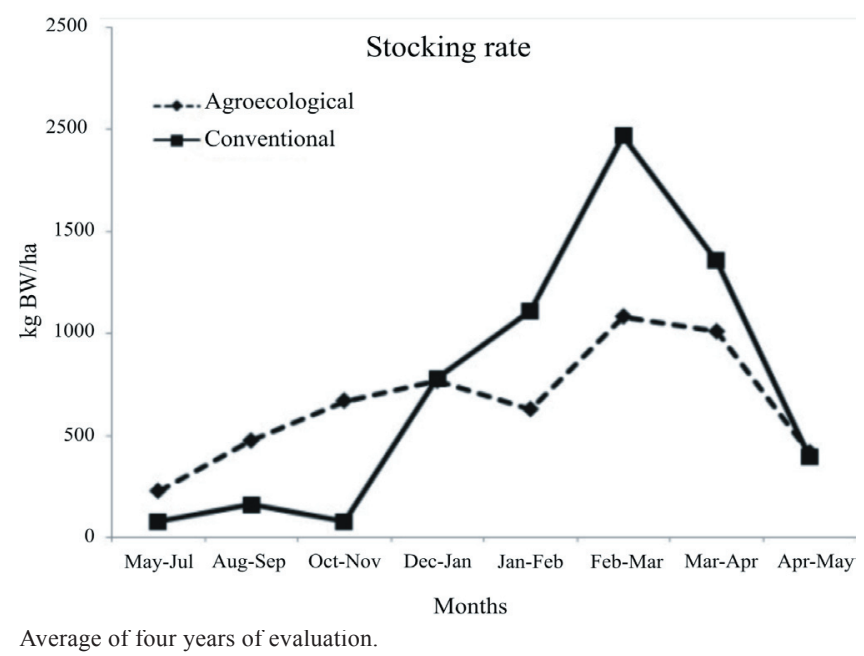

Figure 2 - Stocking rate (AU/ha) during the crop year in elephant grass pastures under conventional and agroecological systems.

system was $1.8 \mathrm{AU} / \mathrm{ha}$. A higher variability was observed in the cool season due to the dependency of elephant grass on the environmental conditions; the highest stocking rate is found in the agroecological pasture due to the contribution of ryegrass, mainly. Similar value to that of the present study was obtained by Sobczak et al. (2005), with 1.53 AU/ ha in pasture managed under the organic production. An average stocking rate of $1.64 \mathrm{AU} / \mathrm{ha}$ was obtained in the cool season under the conventional system by Marchezan et al. (2002) in mixed pastures with ryegrass, white clover and birdsfoot trefoil with diverse levels of fertilization, used by beef cattle. In the warm season the stocking rate values are higher (Figure 2) due to the higher contribution of elephant grass. The average stocking rate value of $1.99 \mathrm{AU} / \mathrm{ha}$ is lower than the 3.01 AU/ha obtained by Olivo et al. (2009) in elephant grass pasture and forage peanut (Arachis pintoi Krap. \& Greg.) subjected to an agroecological transition management.

For the pasture managed under the conventional system the stocking rate is associated with the forage availability. A higher stocking rate, of 4.5 AU/ha was found by Deresz et al. (2001) in a pasture with Napier elephant grass alone, but using a higher level of fertilization during a shorter period of evaluation managed with lactating cows.

\section{Conclusions}

The values of forage mass and stocking rate show that pastures subjected to agroecological management are more frequent used, with a higher number of grazing cycles and a lower dependency on weather conditions. In the conventional production, forage distribution is more irregular in elephant grass alone.

\section{References}

Brasil. Ministério da Agricultura, Pecuária e Abastecimento. 2011. Instrução Normativa n. 46, de 6 de outubro de 2011. Substitui a IN 64 no Regulamento Técnico para os Sistemas Orgânicos de Produção Animal e Vegetal com anexos de insumos permitidos para a produção orgânica. Diário Oficial da República Federativa do Brasil, Brasília, DF, 6 out. 2011.

Dall'Agnol, M.; Scheffer-Basso, S. M.; Nascimento, J. A. L.; Silveira, C. A. M. and Fischer, R. G. 2004. Produção de forragem de capimelefante sob clima frio. Curva de crescimento e valor nutritivo. Revista Brasileira de Zootecnia 33:1110-1117.

Deresz, F.; Lopes, F. C. F. and Aroeira, L. J. M. 2001. Influência de estratégias de manejo em pastagem de capim elefante na produção de leite de vacas Holandês x Zebu. Arquivo Brasileiro de Medicina Veterinária e Zootecnia 53:482-491.

Deresz, F.; Paim-Costa, M. L.; Cóser, A. C.; Martins, C. E. and Abreu, J. B. R. 2006. Composição química, digestibilidade e disponibilidade de capim-elefante cv. Napier manejado sob pastejo rotativo. Revista Brasileira de Zootecnia 35:863-869.

Fonseca, D. M.; Salgado, L. T.; Queiroz, D. S.; Cóser, A. C.; Martins, C. E. and Bonjour, S. C. M. 1998. Produção de leite em pastagem de capim-elefante sob diferentes períodos de ocupação dos piquetes. Revista Brasileira de Zootecnia 27:848-856.

Lima, M. L. P.; Berchielli, T. T.; Leme, P. R.; Nogueira, J. R. and Pinheiro, M. G. 2004. Concentração de nitrogênio uréico plasmático (NUP) e produção de leite de vacas mestiças mantidas em gramíneas tropicais sob pastejo rotacionado. Revista Brasileira de Zootecnia 33:1616-1626

Mannetje, L.'t. 1978. Measuring biomass of grassland vegetation. p.151-178. In: Field and laboratory methods for grassland and animal production research. Mannetje, L.'t and Jones, R. M., eds. CABI Publishing, Cambridge.

Marchesan, E.; Vizzotto, V. R.; Rocha, M. G.; Moojen, E. L. and Silva, J. H. S. 2002. Produção animal em várzea sistematizada cultivada com forrageiras de estação fria submetidas a diferentes níveis de adubação. Ciência Rural 33:303-308.

Moreno, J. A. 1961. Clima do Rio Grande do Sul. Secretaria da Agricultura, Porto Alegre.

Olivo, C. J.; Sobczak, M. F.; Santini Charão, P.; Ziech, M. F.; Rossarolla, G.; Alves Machado, E.; Uberty, L. F. and Schwendler, E. 2006. Evaluation of an elephantgrass pasture, managed under agroecology principles, during the summer period. Livestock Research for Rural Development 18(2). Available at: <http://www. lrrd.org/lrrd18/2/oliv18021.htm>. Accessed on: Dec. 7, 2011.

Olivo, C. J.; Charão, P. S.; Pereira, L. E. T.; Ziech, M. F.; Mainerz, G. and Tyska, D. 2007. Produtividade e valor nutritivo de pasto de capim-elefante manejado sob princípios agroecológicos. Revista Brasileira de Zootecnia 36:1729-1735.

Olivo, C. J.; Ziech, M. F.; Meinerz, G. R.; Agnolin, C. A.; Tyska, D. and Both, J. F. 2009. Valor nutritivo de pastagens consorciadas com diferentes espécies de leguminosas. Revista Brasileira de Zootecnia 38:1543-1552.

Restle, J.; Roso, C.; Aita, V.; Nörnberg, J. L.; Brondani, I. L.; Cerdótes, L. and Carrilho, C. O. 2002. Produção animal em pastagem com gramíneas de estação quente. Revista Brasileira de Zootecnia 31:1491-1500. 
Soares, J. P. G.; Berchielli, T. T.; Aroeira, L. J. M.; Deresz, F. and Verneque, R. S. 2004. Estimativas de consumo do capim elefante (Pennisetum purpureum Schum.), fornecido picado para vacas lactantes utilizando a técnica do óxido crômico. Revista Brasileira de Zootecnia 33:811-820.

Sobczak, M. F.; Olivo, C. J.; Gabbi, A. M.; Charão Santini, P.; Heimerdinger, A.; Souza da Silva, J. H.; Pereira, L. E. T.; Ziech, M. F. and Rossarolla, G. 2005. Evaluation of an elephantgrass pasture mixed with black oat managed under agroecological principles in winter period. Livestock Research for Rural Development 17(6). Available at: <http://www.lrrd.org/lrrd17/6/fati17071.htm>. Accessed on: Dec. 7, 2012.

Streck, E. V.; Kampf, N.; Dalmolin, R. S. D.; Klamt, E.; Nascimento, P. C. and Shnetder, P. 2002. Solos do Rio Grande do Sul. EMATER/RS, Universidade Federal do Rio Grande do Sul, Porto Alegre. 